\title{
Advances in Improving Harvest Index and Grain Yield of Maize in Ethiopia
}

\author{
Mosisa Worku ${ }^{1}$ and Habtamu Zelleke ${ }^{2 *}$ \\ ${ }^{1}$ Ethiopian Institute of Agricultural Research, Bako Agricultural Research Centre, P O Box 3, Ethiopia \\ ${ }^{2}$ Haramaya University, College of Agriculture, Department of Plant Sciences, P O Box 147, Ethiopia
}

\begin{abstract}
The local maize varieties are inefficient in transferring assimilates to the ear sink and as a result they are low yielding. To replace these low yielding local varieties by high yielding ones, different breeding methods have been used in Ethiopia. This study was undertaken to compare improved maize varieties released in Ethiopia for their harvest index and other important agronomic traits. Twelve improved maize varieties which were released from 1970s to 1990s in Ethiopia and 8 breeding populations were tested in a randomized complete block design at Bako Agricultural Research Centre under sub-optimum and optimum soil fertility conditions in 1997 and 1998. The analysis of variance for harvest index and other important agronomic traits showed significant differences $(\mathrm{P}<0.01)$ among the varieties. The mean harvest index varied from $31.1 \%$ (Bako composite) to $45.0 \%$ (BH-540), indicating wide differences among the varieties in partitioning the photosynthate into grain and vegetative plant part. The mean grain yield also varied from 4.3 $\mathrm{t} \mathrm{ha}^{-1}$ (EAH-75) to $7.2 \mathrm{t} \mathrm{ha}^{-1}$ (BH-660). All the varieties released in the 1990s had a better harvest index than the old maize composites, indicating the breeding progress made was successful for both grain yield and harvest index. Further progress in maize breeding to improve harvest index and grain yield would be possible with the use of refined breeding methods and tools.
\end{abstract}

Keywords: Genotype; Grain Yield; Harvest Index; Maize Varieties; Zea mays L.

\section{Introduction}

Local maize varieties were inherently inefficient because of their tall stature, abundant foliage and large tassels that resulted in relatively low harvest index (Benti, 1988; Dowswell et al., 1996). Inefficient transfer of assimilates to the ear sink is also one of the limitations in most of tropical maize materials (Benti et al., 1993).

Maize breeders have explored various breeding methods to shorten tropical maize and increase grain yield and harvest index. Since the major dwarfing genes in maize are associated with some undesirable morphological traits, breeders employed recurrent selection method to shorten plant height and improve grain yield and adaptation of maize germplasm (Johnson et al., 1986; Dowswell et al., 1996).

In Ethiopia, the local maize varieties are low yielding and inefficient in transferring assimilates to the ear sink. To replace these low yielding local varieties by high yielding ones, a nationally co-ordinated maize breeding program was started in the late 1960s. Recurrent selection, introgression of exotic improved materials into locally adapted maize materials followed by recurrent selection and introduction of improved materials from international and national research organisations and selection under local conditions were the methods used to improve grain yield and harvest index of maize (Benti et al., 1993; NMRPPR, 1996). Thus, the objectives of this study were to compare maize varieties released in Ethiopia in the past three decades and other elite maize populations for their harvest index and grain yield and thereby assess progress made in improving these traits.

\section{Materials and Methods}

Twelve improved maize varieties which were released in Ethiopia from 1970s to 1990s and 8 elite breeding populations (Table 1) were tested in a randomised complete block design with three replications at Bako Agricultural Research Centre under sub-optimum and optimum soil fertility conditions $(0 / 0$ and $100 / 100 \mathrm{~kg}$ $\mathrm{N} / \mathrm{P}_{2} \mathrm{O}_{5} \mathrm{ha}^{-1}$ ) during the main season of 1997 and 1998. Bako, with an elevation of 1650 meters above sea level, has relatively good distribution of rainfall for maize production as it receives over $1200 \mathrm{~mm}$ per annum. The soil at Bako is Nitosol with $\mathrm{pH}$ of 5.33 and total phosphorus and nitrogen contents of $9.24 \mathrm{ppm}$ and $0.26 \%$, respectively (Legesse et al., 1987). No fertilizer was applied under the sub-optimum soil fertility condition; while under the optimum soil fertility condition phosphorus (P) was applied at planting. Nitrogen (N) was applied in two splits: the first half applied at planting and the remaining half when the varieties were nearly at knee height stage. Urea and diamonium phosphate (DAP) were used as sources of Nitrogen and Phosphorus fertilizers, respectively. All other agronomic practices were undertaken as recommended for the centre. 
Table 1. Maize Varieties used for the study.

\begin{tabular}{|c|c|c|c|}
\hline Entry No. & Varieties & Year of release & Remark \\
\hline 1 & Alemaya Composite RC-2 & - & Breeding population \\
\hline 2 & Alemaya Composite & $1970 \mathrm{~s}$ & Open pollinated variety \\
\hline 3 & UCB RC-2 & - & Breeding population \\
\hline 4 & $\mathrm{UCB}$ & $1970 \mathrm{~s}$ & Open pollinated variety \\
\hline 5 & Beletech RC-2 & - & Breeding population \\
\hline 6 & Beletech $S_{1} C_{1}$ RC-2 & - & Breeding population \\
\hline 7 & Beletech & 1980s & Open pollinated variety \\
\hline 8 & Late RC-5 & - & Breeding population \\
\hline 9 & Synthetic RC-3 & - & Breeding population \\
\hline 10 & BH-660 & $1990 \mathrm{~s}$ & Hybrid \\
\hline 11 & EAH-75 & 1970s & Open pollinated variety \\
\hline 12 & Bako Composite & 1970s & Open pollinated variety \\
\hline 13 & Kuleni & $1990 \mathrm{~s}$ & Open pollinated variety \\
\hline 14 & INT-A & - & Breeding population \\
\hline 15 & INT-B & - & Breeding population \\
\hline 16 & Gibe-1 & $1999 / 2000$ & Open pollinated variety \\
\hline 17 & BH-140 & $1980 \mathrm{~s}$ & Hybrid \\
\hline 18 & BH-540 & $1990 \mathrm{~s}$ & Hybrid \\
\hline 19 & A-511 & $1970 \mathrm{~s}$ & Open pollinated variety \\
\hline 20 & BH-530 & 1990s & Hybrid \\
\hline
\end{tabular}

The data recorded were grain yield (GY), harvest index (HI), aboveground biomass (AGB), days to female flowering (silking) (DFF), ear height (EH) and plant height (PH). Fresh biomass weights were recorded and samples were also taken and dried to constant weight. Then total aboveground dry matter and harvest index (ratio of economic yield to total aboveground dry matter) were calculated. Grain yield $\left(\mathrm{t} \mathrm{ha}^{-1}\right)$ was calculated using shelling percentage of $80 \%$ and adjusted to $12.5 \%$ moisture content.

Analysis of variance was made for grain yield, harvest index, aboveground biomass, days to female flowering, ear height and plant height. SAS computer program (SAS, 2001) was used for data analysis.

\section{Results and Discussion}

Analysis of variance revealed significant difference $(\mathrm{P}<0.01)$ for all the traits measured among the varieties under both fertility conditions in both years (Tables 2 and 3). The combined analysis of variance also showed that the effects of the genotypes were significant $(\mathrm{P}<0.01)$ for all traits measured (Table 4). The significant effect of genotype for harvest index indicates that the genotypes varied in partition of their total biomass to grain. On the other hand, interactions of genotype with year, genotype with soil fertility level, and genotype with fertility level and with year were not significant for harvest index, indicating the consistency of performance of the varieties for harvest index across years and soil fertility conditions. This implied possibility of determining harvest index of genotypes under both sub-optimum and optimum soil fertility conditions. However, the result may be different under severe stress of soil fertility conditions as less biomass is partitioned to reproductive structures under very low soil fertility conditions (Andrade et al., 1999). Although grain yield reduction was less than $50 \%$ under low soil fertility conditions in both years (Table 2), the interaction effects of genotype by year, genotype by soil fertility level and genotype by soil fertility level by year were significant for grain yield (Table 4), indicating the inconsistency of performance of some varieties over years and soil fertility conditions. In both years, BH660 was the highest yielding in both soil fertility levels. 
Table 2. Grain yield (GY, $\mathrm{t} \mathrm{ha}^{-1}$ ), harvest index (HI, \%), aboveground biomass (AGB, $\mathrm{t} \mathrm{ha}^{-1}$ ) of 12 released maize varieties and 8 breeding populations evaluated at Bako western Ethiopia, in 1997 and 1998 under sub-optimum and optimum soil fertility levels

\begin{tabular}{|c|c|c|c|c|c|c|c|c|c|c|c|c|}
\hline \multirow[b]{3}{*}{ Entry No. } & \multicolumn{6}{|l|}{1997} & \multicolumn{6}{|l|}{1998} \\
\hline & \multicolumn{3}{|c|}{ Sub-optimum } & \multicolumn{3}{|c|}{ Optimum } & \multicolumn{3}{|c|}{ Sub-optimum } & \multicolumn{3}{|c|}{ Optimum } \\
\hline & GY & $\mathrm{HI}$ & AGB & GY & $\mathrm{HI}$ & AGB & GY & $\mathrm{HI}$ & AGB & GY & $\mathrm{HI}$ & AGB \\
\hline 1 & 5.1 & 42.8 & 10.6 & 7.0 & 40.3 & 15.2 & 3.8 & 40.8 & 8.0 & 6.9 & 42.5 & 14.5 \\
\hline 2 & 4.1 & 35.9 & 10.2 & 7.1 & 34.7 & 17.8 & 4.4 & 35.8 & 10.7 & 6.2 & 34.3 & 13.3 \\
\hline 3 & 4.9 & 41.5 & 10.2 & 7.1 & 40.8 & 15.3 & 4.2 & 40.7 & 9.0 & 6.4 & 39.7 & 14.2 \\
\hline 4 & 4.4 & 33.8 & 11.4 & 7.2 & 33.5 & 18.9 & 3.3 & 34.5 & 8.6 & 6.9 & 38.3 & 15.6 \\
\hline 5 & 4.0 & 41.2 & 8.5 & 5.5 & 36.8 & 13.2 & 3.2 & 42.0 & 6.8 & 5.3 & 40.2 & 11.5 \\
\hline 6 & 4.0 & 42.7 & 8.3 & 6.7 & 39.1 & 14.9 & 3.5 & 39.1 & 7.7 & 5.5 & 40.3 & 12.0 \\
\hline 7 & 4.0 & 37.4 & 9.4 & 7.4 & 37.1 & 17.4 & 2.8 & 35.5 & 6.9 & 5.9 & 40.4 & 12.7 \\
\hline 8 & 4.6 & 38.8 & 10.3 & 7.4 & 33.6 & 19.4 & 3.4 & 33.7 & 8.6 & 6.8 & 37.3 & 15.9 \\
\hline 9 & 5.0 & 42.3 & 10.4 & 7.8 & 38.6 & 17.5 & 3.1 & 35.6 & 7.4 & 6.2 & 41.2 & 12.3 \\
\hline 10 & 6.2 & 42.5 & 12.8 & 8.5 & 36.7 & 20.3 & 4.7 & 41.4 & 9.8 & 9.5 & 44.5 & 18.6 \\
\hline 11 & 3.0 & 33.1 & 7.9 & 5.6 & 31.0 & 16.0 & 2.9 & 32.7 & 7.8 & 5.6 & 38.8 & 12.5 \\
\hline 12 & 4.7 & 33.0 & 12.3 & 6.8 & 31.1 & 19.1 & 2.8 & 28.7 & 8.6 & 6.0 & 31.6 & 16.4 \\
\hline 13 & 3.9 & 40.6 & 8.5 & 7.0 & 38.1 & 16.2 & 3.9 & 38.4 & 8.5 & 6.9 & 42.9 & 14.1 \\
\hline 14 & 3.3 & 40.7 & 7.1 & 6.6 & 43.6 & 13.2 & 2.2 & 37.6 & 5.2 & 5.9 & 49.2 & 10.5 \\
\hline 15 & 4.4 & 43.2 & 8.8 & 7.0 & 40.0 & 15.5 & 3.3 & 42.0 & 6.8 & 5.7 & 43.9 & 11.2 \\
\hline 16 & 4.7 & 42.6 & 9.6 & 8.2 & 43.9 & 16.5 & 4.5 & 44.2 & 8.8 & 9.0 & 45.2 & 17.5 \\
\hline 17 & 4.4 & 43.6 & 8.8 & 7.4 & 44.1 & 14.8 & 4.1 & 40.8 & 8.9 & 7.2 & 44.7 & 14.2 \\
\hline 18 & 4.1 & 41.7 & 8.4 & 7.8 & 43.3 & 15.7 & 4.4 & 46.7 & 8.3 & 8.2 & 48.1 & 15.0 \\
\hline 19 & 4.1 & 42.8 & 8.5 & 7.0 & 43.7 & 14.1 & 3.7 & 40.1 & 8.1 & 5.3 & 41.2 & 11.0 \\
\hline 20 & 4.8 & 42.0 & 10.2 & 8.4 & 42.7 & 17.1 & 4.3 & 40.5 & 9.2 & 6.5 & 43.2 & 13.4 \\
\hline Mean & 4.4 & 40.1 & 9.6 & 7.2 & 38.6 & 16.4 & 3.6 & 38.5 & 8.2 & 6.6 & 41.4 & 13.8 \\
\hline F-test & $* *$ & $* *$ & $* *$ & ** & $* *$ & $* *$ & ** & $* *$ & $* *$ & $* *$ & $* *$ & $* *$ \\
\hline $\mathrm{CV}(\%)$ & 13.1 & 7.4 & 10.6 & 9.5 & 8.5 & 10.4 & 14.1 & 9.0 & 12.7 & 9.9 & 10.7 & 13.0 \\
\hline $\operatorname{LSD}(0.05)$ & 0.9 & 4.9 & 1.7 & 1.1 & 5.4 & 2.8 & 0.8 & 5.7 & 1.7 & 1.1 & 7.3 & 3.0 \\
\hline
\end{tabular}


Table 3. Days to female flowering (DFF), ear height $(\mathrm{EH}, \mathrm{cm})$, plant height $(\mathrm{PH}, \mathrm{cm})$ of 12 released maize varieties and 8 breeding populations evaluated at Bako western Ethiopia, in 1997 and 1998 under sub-optimum and optimum soil fertility levels

\begin{tabular}{|c|c|c|c|c|c|c|c|c|c|c|c|c|}
\hline \multirow[b]{3}{*}{ Entry No. } & \multicolumn{6}{|l|}{1997} & \multicolumn{6}{|l|}{1998} \\
\hline & \multicolumn{3}{|c|}{ Sub-optimum } & \multicolumn{3}{|c|}{ Optimum } & \multicolumn{3}{|c|}{ Sub-optimum } & \multicolumn{3}{|c|}{ Optimum } \\
\hline & DFF & $\mathrm{EH}$ & $\mathrm{PH}$ & DFF & EH & $\mathrm{PH}$ & DFF & $\mathrm{EH}$ & $\mathrm{PH}$ & DFF & EH & $\mathrm{PH}$ \\
\hline 1 & 81 & 98 & 225 & 73 & 137 & 277 & 75 & 97 & 210 & 69 & 107 & 227 \\
\hline 2 & 84 & 108 & 238 & 76 & 137 & 260 & 81 & 122 & 228 & 75 & 172 & 278 \\
\hline 3 & 80 & 112 & 227 & 73 & 112 & 242 & 78 & 92 & 203 & 68 & 120 & 245 \\
\hline 4 & 87 & 145 & 297 & 81 & 153 & 272 & 82 & 113 & 223 & 74 & 165 & 288 \\
\hline 5 & 77 & 78 & 202 & 73 & 133 & 253 & 75 & 95 & 190 & 67 & 108 & 237 \\
\hline 6 & 77 & 102 & 220 & 71 & 122 & 243 & 75 & 87 & 195 & 66 & 127 & 248 \\
\hline 7 & 83 & 110 & 217 & 78 & 117 & 247 & 79 & 107 & 218 & 72 & 133 & 255 \\
\hline 8 & 83 & 132 & 232 & 77 & 165 & 277 & 85 & 120 & 228 & 71 & 153 & 273 \\
\hline 9 & 83 & 93 & 205 & 77 & 128 & 253 & 79 & 97 & 225 & 70 & 138 & 250 \\
\hline 10 & 78 & 118 & 232 & 82 & 157 & 270 & 84 & 118 & 235 & 72 & 160 & 277 \\
\hline 11 & 85 & 172 & 250 & 83 & 150 & 272 & 82 & 125 & 235 & 72 & 153 & 272 \\
\hline 12 & 86 & 148 & 270 & 82 & 162 & 290 & 85 & 123 & 238 & 75 & 193 & 300 \\
\hline 13 & 88 & 90 & 212 & 74 & 122 & 240 & 75 & 100 & 205 & 66 & 120 & 255 \\
\hline 14 & 78 & 68 & 167 & 69 & 90 & 203 & 73 & 62 & 164 & 65 & 88 & 208 \\
\hline 15 & 74 & 72 & 193 & 68 & 97 & 203 & 71 & 85 & 173 & 65 & 95 & 217 \\
\hline 16 & 73 & 85 & 208 & 76 & 100 & 240 & 75 & 88 & 198 & 68 & 98 & 240 \\
\hline 17 & 80 & 80 & 225 & 77 & 103 & 220 & 75 & 100 & 193 & 71 & 113 & 223 \\
\hline 18 & 79 & 82 & 193 & 79 & 120 & 232 & 73 & 85 & 198 & 69 & 122 & 235 \\
\hline 19 & 86 & 95 & 195 & 67 & 97 & 233 & 67 & 90 & 207 & 60 & 97 & 222 \\
\hline 20 & 71 & 97 & 215 & 76 & 115 & 245 & 74 & 77 & 192 & 68 & 102 & 232 \\
\hline Mean & 81 & 104 & 221 & 76 & 126 & 249 & 77 & 99 & 208 & 69 & 128 & 249 \\
\hline F-test & $* *$ & $* *$ & $* *$ & $* *$ & $* *$ & $* *$ & $* *$ & $* *$ & $* *$ & $* *$ & $* *$ & $* *$ \\
\hline CV (\%) & 2.2 & 18.4 & 11.1 & 2.5 & 14.5 & 6.4 & 3.4 & 14.1 & 5.9 & 3.3 & 11.9 & 5.9 \\
\hline $\operatorname{LSD}(0.05)$ & 2.9 & 31.7 & 40.7 & 3.1 & 30.2 & 26.2 & 4.9 & 23.2 & 20.2 & 3.8 & 25.3 & 24.4 \\
\hline
\end{tabular}

\section{$* *=$ Significant at 0.01 levels of probability}

The mean harvest index over all the environments was $39.7 \%$, with individual genotypic mean ranging from $31.1 \%$ (Bako composite) to $45.0 \%$ (BH-540), indicating variability among the varieties in transferring assimilates to the ear sink. Genotypic differences were also observed for mean total aboveground biomass production that ranged from 9.0 to $15.4 \mathrm{t} \mathrm{ha}^{-1}$. The mean grain yield ranged from $4.3 \mathrm{tha}^{-1}$ (EAH-75) to $7.2 \mathrm{t} \mathrm{ha}^{-1}$ (BH-660) as shown in Table 5.

Aboveground biomass, ear height and, plant height were reduced under low soil fertility conditions. On the other hand, days to female flowering (silking) was delayed under low soil fertility condition in both years
(Tables 2 and 3). Edmeades et al. (1993) also found similar results in tropical lowland maize under stress conditions. Harvest index was negatively correlated with plant height $(\mathrm{r}=-0.83)$, ear height $(\mathrm{r}=-0.87)$ and days to silking $(r=-0.67)$, indicating that the tall late maturing old composites were poor in partitioning of assimilates to the economic yield. These old composites had also relatively high total aboveground biomass, however, they had low harvest index. Similar results were reported by Johnson et al. (1986) in which they indicated that unimproved tropical maize materials have low harvest index. 
Table 4. Combined analysis of variance for harvest index (HI), grain yield (GY), aboveground biomass (AGB), days to female flowering (DFF) and ear height $(\mathrm{EH})$ and plant height $(\mathrm{PH})$ of 12 released maize varieties and 8 breeding populations tested at Bako western Ethiopa, in 1997 and 1998

\begin{tabular}{|c|c|c|c|c|c|c|c|}
\hline \multirow[t]{2}{*}{ Source } & \multirow[t]{2}{*}{$\mathrm{df}$} & \multicolumn{6}{|c|}{ Mean squares } \\
\hline & & $\mathrm{HI}$ & GY & AGB & $\mathrm{EH}$ & $\mathrm{PH}$ & DFF \\
\hline Year $(Y)$ & 1 & $20.5^{\mathrm{ns}}$ & $27.3^{* *}$ & $242.4 * *$ & $106.7^{\mathrm{ns}}$ & $2356.3 * *$ & $1470.2 * *$ \\
\hline $\begin{array}{l}\text { Fertility env. } \\
\text { (FE) }\end{array}$ & 1 & $28.3^{\mathrm{ns}}$ & $494.6 * *$ & $2315.6^{* *}$ & $38506.7 * *$ & $70452.3 * *$ & $2653.4 * *$ \\
\hline $\mathrm{Y} \times \mathrm{FE}$ & 1 & $281.2 * *$ & $0.5^{\mathrm{ns}}$ & $20.4^{* *}$ & $881.7^{\mathrm{ns}}$ & $2747.3 * *$ & $163.4 * *$ \\
\hline $\mathrm{R} /(\mathrm{FE} \times \mathrm{Y})$ & 8 & $33.3 *$ & $2.9 * *$ & $14.8 * *$ & $512.9^{\mathrm{ns}}$ & $856.8 * *$ & $24.3 * *$ \\
\hline Genotypes (G) & 19 & $166.0 * *$ & $6.0 * *$ & $27.6^{* *}$ & $6072.7 * *$ & $6223.7 * *$ & $220.7 * *$ \\
\hline$Y \times G$ & 19 & $12.7^{\mathrm{ns}}$ & $1.0 * *$ & $3.7 *$ & $358.2^{\mathrm{ns}}$ & $379.8^{\mathrm{ns}}$ & $15.8 * *$ \\
\hline FE x G & 19 & $13.7^{\mathrm{ns}}$ & $1.0 * *$ & $3.9 *$ & $410.4^{\mathrm{ns}}$ & $216.4^{\mathrm{ns}}$ & $6.9^{\mathrm{ns}}$ \\
\hline$Y \times F E \times G$ & 19 & $8.6^{\mathrm{ns}}$ & $0.6^{*}$ & $2.5^{\mathrm{ns}}$ & $460.4^{\mathrm{ns}}$ & $563.2^{\mathrm{ns}}$ & $7.8^{\mathrm{ns}}$ \\
\hline Error & 152 & 12.8 & 0.4 & 2.1 & 283.6 & 306.2 & 5.2 \\
\hline
\end{tabular}

$*, * *=$ Significant at $p<0.05$ and $p<0.01^{n s}=$ Not significant at $p>0.05$

On the other hand, the relatively early maturing varieties (NT-A, ENT-B and A-511) had low grain yield and aboveground biomass but harvest index was over $40 \%$ (Table 5). The earlier version of Beletech, Beletech $\mathrm{S}_{1} \mathrm{C}_{1} \mathrm{RC}-2$, which was developed through $\mathrm{S}_{1}$ selection had also better harvest index than the original Beletech. However, the improved version had relatively lower aboveground biomass and grain yield than Beletech. This showed high harvest index alone could not indicate high grain yield. Hence, it is important to select for both plant architecture and high biological yields along with high harvest index. Similar conclusion was made by Frey (1984). In this experiment, the high yielding varieties, BH-660 and Gibe-1, had also high aboveground biomass and harvest index, which indicated the importance of improvement for both traits. In addition, the simple linear correlation analysis showed positive relationship $(\mathrm{r}=0.69)$ between aboveground biomass and grain yield.

Beletech which was developed from Bako composite through full-sib family selection under the optimum soil fertility condition (Benti et al., 1993) had better harvest index than the original composite which implied the successful improvement of harvest index through recurrent selection (Table 5). Johnson et al. (1986) also reported the successful improvement of harvest index through recurrent selection in tropical maize, Tuxpeno-1.

Alemaya composite RC-2 and UCB RC-2 were synthesised by introgressing CIMMYT, Pioneer and selected East African germplasm into Alemaya composite and UCB, respectively (NMRPPR, 1996). The two breeding populations had better grain yield and harvest index than the original composites which indicated the possibility of improving harvest index and grain yield through selection following introgression of improved genotypes into locally adapted materials. Gibe-1 was also synthesised from selected East African, Pioneer and CIMMYT materials. Mass selection was used to improve this population and it had better grain yield and harvest index than all the other open pollinated varieties. This also showed that the East African maize breeders could improve the harvest index and grain yield of locally adapted maize genotypes through introgression followed by selection. On the other hand, Late RC-5 which was mainly synthesised from locally adapted East African materials was inferior in harvest index and grain yield as compared to the other improved materials.

Kuleni (Pool-9A) was selected from introduced CIMMYT materials (Benti et al., 1993) and this variety had better harvest index, grain yield and other agronomic traits than the old East African composites. This also indicate that the CIMMYT improved maize materials have better harvest indices than the East African composites and hence, CIMMYT could be a good source of improved germplasm for East African maize breeding programs. In addition, CIMMYT improved maize materials were shorter than the old East African composites. This permits cultivation of high density plant stands and provides new intercropping alternatives for the farmers (Dowswell et al., 1996). Most of the East African materials were tolerant to leaf diseases (data not presented) and they could be good sources of genes for disease resistance.

All the varieties released in the 1990s had better harvest indices than the old composites, indicating that the progress made is not only for grain yield but also for 
harvest index (Figures 1 and 2). When the mean grain yields and harvest indices of all the varieties released in the 1990s were compared to the mean grain yields and harvest indices of the varieties released in the 1970s, the mean grain yields and harvest indices were increased by 24 and $20 \%$, respectively. The new maize varieties had harvest indices above $40 \%$ while the old composites had below $40 \%$ except A-511. This indicates the progress made over the years in improving grain yield and harvest index in Ethiopia. Dowswell et al. (1996) reported that the harvest index of most improved tropical maize increased from about $30 \%$ to $43 \%$ and the present study also proved similar trends. The simple linear correlation analysis also showed positive relationship $(r=0.40)$ between grain yield and harvest index.

The superiority of the new maize varieties in harvest index as compared to the old composites also indicated that the new maize varieties allocate much of the available photosynthetic products to the grain as compared to the old composites. This has been reflected in their better response in grain yield to favourable soil fertility condition than the old composites. Sinclair
(1998) reported that the germplasm with nitrogen and other assimilates will allocate to the grain to allow subsequent increases in harvest index.

The present study clearly demonstrated that better grain yield performance of the improved open pollinated and hybrid varieties is mainly due to an increase in harvest index. It also indicated that harvest index of the East African old maize composites could be improved through introgression of other improved materials into them followed by recurrent selection. The study also demonstrated that the CIMMYT improved germplasm had better harvest indices than the East African old maize composites. Thus, the CIMMYT improved germplasm could be potential sources to develop improved varieties in East Africa.

Although all the hybrids tested in this experiment had harvest indices of $40-45 \%$, further improvement is necessary to develop hybrids with better harvest index. The success of US maize breeders who have already achieved 50-55\% harvest index for the US maize belt hybrids (Dowswell et al., 1996) could be a good example for the national maize breeders.

Table 5. Mean performance for days to female flowering (DFF), ear height (EH), plant height (PH), grain yield (GY), aboveground biomass (AGB) and harvest index (HI) of 12 released maize varieties and 8 breeding populations tested at Bako in 1997 and 1998.

\begin{tabular}{lllllll}
\hline Entry No. & DFF & EH $(\mathrm{cm})$ & PH $(\mathrm{cm})$ & GY $\left(\mathrm{t} \mathrm{ha}^{-1}\right)$ & AGB $\left(\mathrm{t} \mathrm{ha}^{-1}\right)$ & HI $(\%)$ \\
\hline 1 & 74 & 110 & 235 & 5.7 & 12.1 & 41.6 \\
2 & 79 & 135 & 251 & 5.5 & 14.0 & 35.2 \\
3 & 75 & 109 & 229 & 5.6 & 12.2 & 40.7 \\
4 & 81 & 144 & 270 & 5.5 & 13.6 & 35.0 \\
5 & 73 & 104 & 220 & 4.5 & 10.0 & 40.0 \\
6 & 72 & 109 & 227 & 4.9 & 10.7 & 40.3 \\
7 & 78 & 117 & 234 & 5.0 & 11.6 & 37.6 \\
8 & 79 & 143 & 253 & 5.6 & 13.6 & 35.8 \\
9 & 76 & 114 & 233 & 5.5 & 12.0 & 39.4 \\
10 & 81 & 138 & 253 & 7.2 & 15.4 & 41.3 \\
11 & 81 & 150 & 257 & 4.3 & 11.1 & 33.9 \\
12 & 83 & 157 & 275 & 5.1 & 14.1 & 31.1 \\
13 & 74 & 108 & 228 & 5.5 & 11.8 & 40.0 \\
14 & 70 & 77 & 186 & 4.5 & 9.0 & 42.8 \\
15 & 69 & 87 & 197 & 5.1 & 10.6 & 42.3 \\
16 & 75 & 93 & 222 & 6.6 & 13.1 & 44.0 \\
17 & 76 & 99 & 215 & 5.8 & 11.7 & 43.3 \\
18 & 77 & 102 & 215 & 6.2 & 12.0 & 45.0 \\
19 & 66 & 95 & 214 & 5.1 & 10.4 & 42.0 \\
20 & 75 & 98 & 221 & 6.0 & 12.5 & 42.1 \\
\hline Mean & 76 & 114 & 232 & 5.5 & 12.1 & 39.7 \\
\hline CV (\%) & 3.0 & 14.7 & 7.6 & 11.2 & 12.0 & 9.0 \\
LSD 0.05 & 3.6 & 27.0 & 28.0 & 1.0 & 2.3 & 5.7 \\
\hline
\end{tabular}




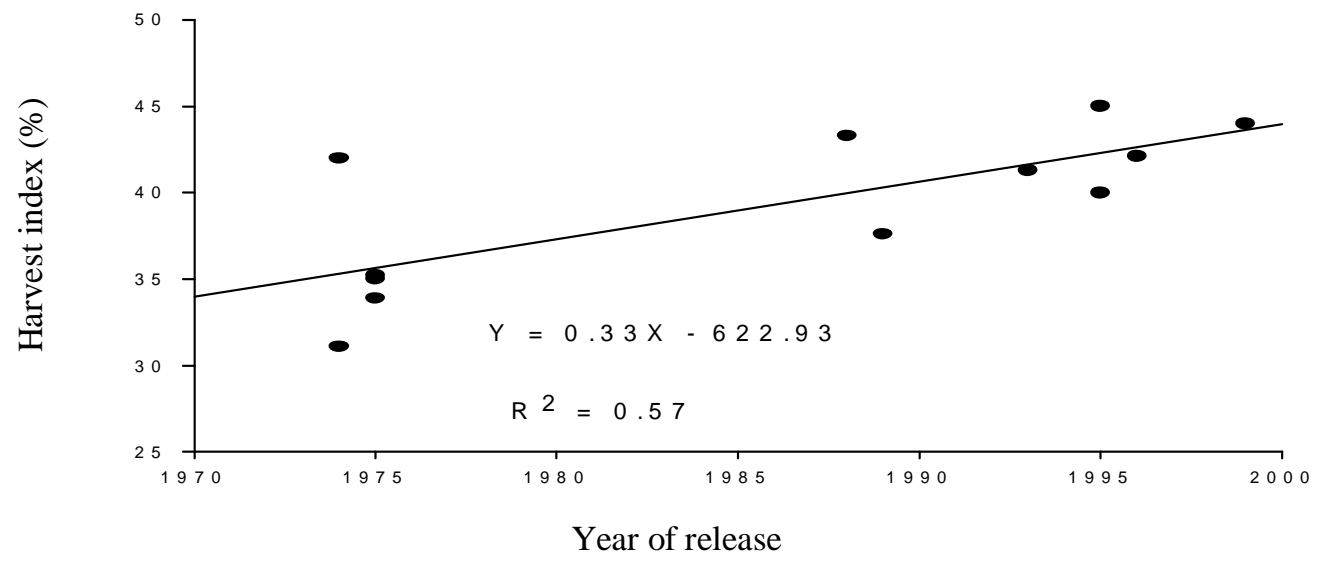

Figure 1. Mean harvest index of 12 maize varieties released in Ethiopia from 1970 to 2000.

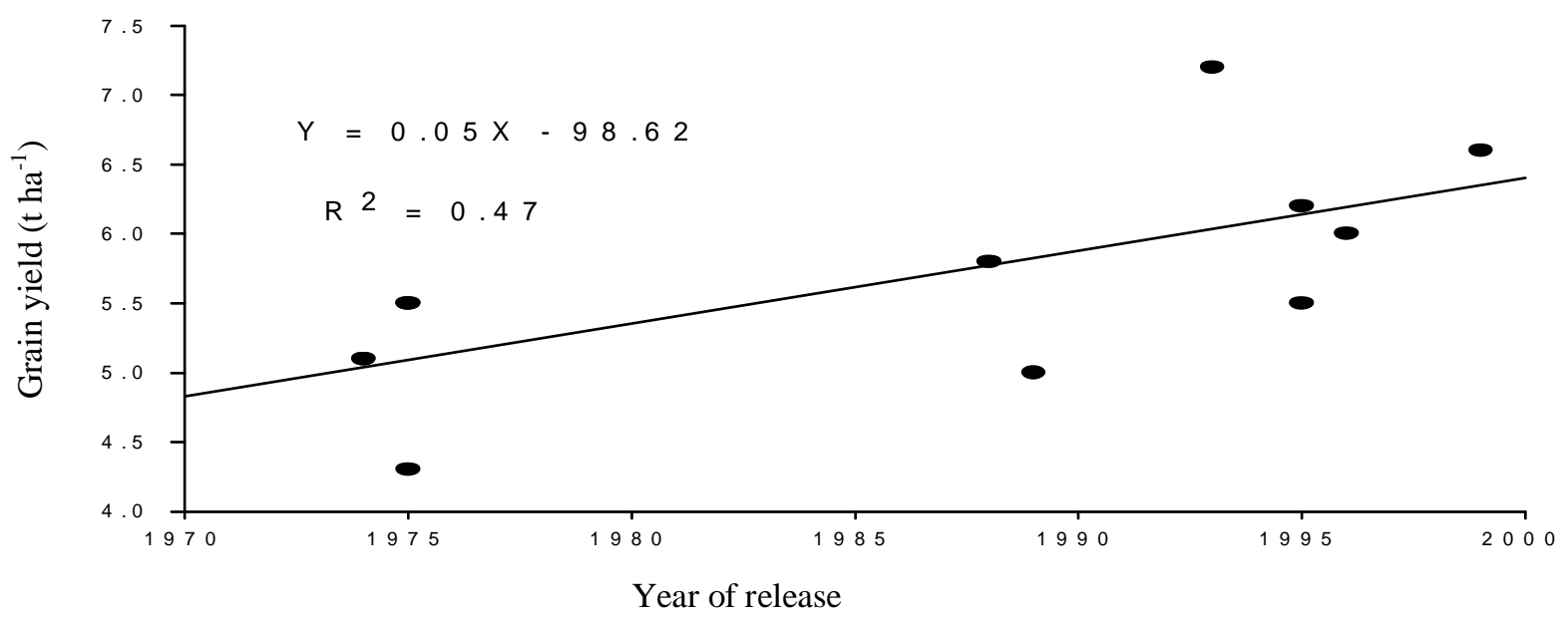

Figure 2. Mean grain yield of 12 maize varieties released in Ethiopia from 1970 to 2000.

\section{Acknowledgements}

The authors wish to thank Dr. Benti Tolessa, Legesse Wolde, Wende Abera, Aschalew Guta, Molla Assefa, Gudeta Nepir, Dinsa Duguma and Yohanis Tolessa for their assistance in organizing and conducting the trial.

\section{References}

Andrade, F.H., Vega, C., Uhart, S., Cirilo, A., Cantarero, M. and Valentinuz, O. 1999. Kernel number determination in maize. Crop Science 39: 453-459.

Benti, T. 1988. Genetic improvement of maize in Ethiopia: Strategies and progress made. In: Towards Self Sufficiency: Proceedings of the Second Eastern, Central and Southern Africa Regional Maize Workshop, 15-21 March 1987, CIMMYT, Harare, Zimbabwe. pp. 4760.
Benti, T., Tasew, G., Mosisa, W., Yigzaw, D., Kebede, M. and Gezehegne, B. 1993. Genetic improvement of maize in Ethiopia: A Review. In: Benti, T. and Ransom J. K. (eds.). Proceedings of the First National Maize Workshop of Ethiopia, 5-7 May 1992. IAR/CIMMYT, Addis Ababa, Ethiopia. pp. 13-21.

Dowswell, C. R., Paliwal, R. L. and Cantrell, R. P. 1996. Maize in the Third World. West views Press, Inc. Colorado, USA. pp. 117-119.

Edmeades, G.O., Bolanos, J., Hernandez, M. and Bello, S. 1993. Causes for silk delay in a lowland tropical population. Crop Science 33: 10291035.

Frey, K. J. 1984. Breeding approaches for increasing cereal crop yields. In: Gallagher E. J. (ed.). Cereal Production. Butterworth and Co (Publishers) Ltd., London. pp. 47-68. 
Johnson, E. C., Fisher, K. S., Edmeades, G. O. and Palmer, A. F. E. 1986. Recurrent selection for reduced plant height in low land tropical maize. Crop Science 26: 253-260.

Legesse, D., Gemechu, G., Tesfaye, K. and Getahun, D. 1987. Diagnostic survey of Bako mixed farming system in Wellega and Shoa regions. Research Report No. 1, IAR, Addis Ababa, Ethiopia. pp. 2-6.

NMRPPR (National Maize Research Program Progress Report) 1996. Bako Research Center, Bako, Ethiopia. pp. 1-20.

SAS Institute. 2001. The SAS System for Windows Release 8.02. SAS Institute Inc., Cary, NC.

Sinclair, T. R. 1998. Historical changes in harvest index and crop nitrogen accumulation. Crop Science 38 (3): 638-643. 